\title{
Gerakan Agama dan Budaya Komunitas Sekelik Sedulur dalam Mencegah Konflik Etnis di Lampung Tengah
}

\author{
M. Ali Syufa'at \\ Heri Cahyono \\ Universitas Muhammadiyah Metro \\ Ahmad Madkur \\ IAIN Metro \\ hericahyono@gmail.com
}

\begin{abstract}
This current paper discusses the movement Sekelik Sedulur community in building a culture of inter-ethnic harmony Lampung and Java as an attempt to Prevent ethnic conflict in Central Lampung. The core foundation of this community used a part of a cultural approach Harmony Among maintain ethnic, religious and community groups in Central Lampung. 'Sekelik' in Lampung means 'brother' and 'sedulur' in Javanese language means 'brother'. Community Sekelik Sedulur actively makes the discussion, friendship, and cultural acculturation activities in maintaining inter-ethnic relations. As Lampungnese were famous with the ethnic conflict, economic and social dialogue, it is Necessary to conduct forum as a form of concern for inter-ethnic harmony. Actually, the problems is there is no action blended multicultural entities. This study uses ethnographic approach. To answer the questions of this research, Utilization thinking of Koentjaraningrat Cultural is used as acculturation theory. Acculturation is a cultural fusion that occurs when a group of people with a certain culture are confronted with elements of a foreign culture so that different elements of foreign culture are gradually accepted and processed into their own culture without losing their own cultural identity.
\end{abstract}

Key Words: Sekelik Sedulur Community, Intellectual Collective, Harmony and Cultural acculturation

\begin{abstract}
Abstrak
Penelitian ini mengungkap gerakan komunitas Sekelik Sedulur dalam membangun harmoni budaya antar etnis Lampung dan Jawa sebagai upaya mencegah konflik etnis di Lampung Tengah. Sejak berdiri kelompok ini menggunakan pendekatan budaya sebagai bagian memelihara kerukunan antara etnis, agama, dan golongan yang ada di masyarakat Lampung Tengah. 'Sekelik' dalam bahasa Lampung berarti 'saudara' dan 'sedulur' dalam bahasa jawa berarti 'saudara'. Komunitas Sekelik Sedulur aktif melakukan diskusi, silaturahim, dan kegiatan akulturasi kebudayaan dalam memelihara hubungan antar etnis. Sebagaimana masyarakat Lampung yang sangat terkenal dengan konflik etnis, sosial dan ekonomi maka perlu melakukan dialog lintas golongan sebagai bentuk kepedulian terhadap kerukunan antar etnis. Permasalahan yang muncul sebenarnya adalah kurangnya tindakan membaur di entitas-entitas multikultur. Penelitian ini menggunakan pendekatan etnografi dan untuk menjawab pertanyaan yang diajukan penelitian ini mendayagunakan pemikiran Koentjaraningrat yaitu teori Akulturasi Budaya. Akulturasi adalah perpaduan kebudayaan yang terjadi bila suatu kelompok manusia dengan suatu kebudayaan tertentu dihadapkan dengan unsur-unsur dari suatu kebudayaan asing yang berbeda sehingga unsur-unsur kebudayaan asing itu dengan lambat laun diterima dan diolah kedalam kebudayaan sendiri tanpa menghilangkan kepribadian kebudayaan sendiri.
\end{abstract}

Kata Kunci: Sekelik Sedulur, Intelektual Kolektif, Harmoni, dan Akulturasi Budaya 


\section{Pendahuluan}

Konflik adalah tragedi kemanusiaan yang menyisakan luka berkepanjangan dan menimbulkan kerugian bagi banyak pihak. Tesis Dahrendrof menyebutkan bahwa konsensus dan konflik hadir sekaligus dalam masyarakat sebagai hubungan sebab akibat. Masyarakat tidak akan mempunyai konflik tanpa ada konsensus atau kesepakatan sebelumnya. Konflik terjadi karena telah melanggar konsensus. ${ }^{1}$ Dalam kasus berbaurnya masyarakat Lampung dan Jawa jauh sebelum Indonesia merdeka konsensus itu sudah terbentuk sebagai bagian dialektika kebudayaan satu sama lain. Maka sebenarnya konflik muncul dari persepsi mengenai perbedaan kepentingan (perceived divergence of interest). ${ }^{2}$ Jawa sebagai suku pendatang di bumi Lampung sebisa mungkin dapat beradaptasi dengan masyarakat Lampung agar tidak terjadi konflik.

Konflik juga dapat dipicu oleh dominasi kekuasaan. Dalam ranah etnis kekuasaan primordial atau pemangku kepentingan adat masing-masing dapat mempengaruhi terjadinya konflik. Dalam hal ini, posisi kekuasaan antara suku satu dan yang lainnya merasa saling terancam sehingga pengaruh elit dapat menambah lebar konflik yang sebenarnya hanya terjadi pada akar rumput. Dalam hal ini, kekerasan terorganisir dan didorong oleh legitimasi kekuasaan tertentu. Kekerasan ini disebut sebagai 'kekerasan struktural'. ${ }^{3}$ Kekerasan struktural terjadi atas legitimasi kekuasaan, ketidakadilan pembangunan, peminggiran budaya tertentu oleh dominasi elit penguasa, sehingga menjadikan kekerasan struktural ini melahirkan konflik berkepanjangan. Kepemimpinan yang tidak memberikan keadilan bagi semua, atau hanya mengunggulkan sebagian golongan menjadikan struktur-struktur masyarakat semakin terpecah belah. Giddens ${ }^{4}$ menyebut ada dua faktor penyebab kekerasan struktural tersebut. Pertama, dominasi tokoh elit dan kedua, legitimasi atas perlakuan berbeda. Konflik terjadi bukan hanya soal suku, ras, agama dan antar golongan (SARA), tapi konflik bisa terjadi akibat faktor ekonomi dan politik. Konflik kemudian melebar menjadi fenomena kerusuhan ke wilayah SARA.

Kymlicka berpendapat tentang inklusifitas didasarkan pada nalar liberal, mendudukan inklusi kelompok yang spesifik seperti komunitas adat atau agama yang harus menjalankan prinsip-prinsip demokrasi liberal yaitu kesetaraan dan partisipasi. ${ }^{5}$ Namun lain halnya dengan Parekh bahwa prinsip liberalisme akan 2003), h. 154

1 George Ritzer \& Douglas J. Goodman, Teori Sosiologi Modern, (Jakarta: Pernada Media,

2 Dean G Pruitt \& Jeffrey . Rubin, Teori Konflik Sosial, (Yogyakarta: Pustaka Pelajar, 2004), h. 21

${ }^{3}$ Haryatmoko, Etika Politik Kekuasaan, (Jakarta: Kompas, 2003), h. 48

4 Anthony Giddens, Teori Strukturasi untuk Analisis Sosial. (Pasuruan: Pedati, 2003), h. 313

5 Kymlicka, W, Multicultural Citicenship: Liberal theory of Minority Rights, (Oxford: Clarendon Press, 1995).

| RI'AYAH, Vol. 02, No. 01 Januari-Juni 2017 
sulit dipraktikkan jika demokrasi belum menjadi norma dan perilaku. ${ }^{6}$ Masyarakat atau komunitas yang tidak dibangun dengan partisipasi aktif antar individu akan menemukan kesulitannya. Kaitannya dengan fakta multikulturalisme dalam praktik harmoni akan mengalami hambatan.

Salah satu penyebab kekerasan struktural terus berlangsung adalah akibat dari sikap diam dan pasrah (pasivitisme). Biasanya sikap ini ditunjukkan oleh para minoritas karena ketidakberdayaan menghadapi kekerasan yang berlangsung. Maka kekerasan akan tetap terjadi, sebagaimana Frans Magnis Suseno menyatakan bahwa kekerasan dan ketidakadilan dilegalkan dan dipertahankan oleh sikap pasif dalam diri manusia itu sendiri. ${ }^{7}$

Salmi membagi kekerasan dalam empat kategori, yaitu kekerasan langsung, tidak langsung, kekerasan represif, dan kekerasan aleniatif. ${ }^{8}$ Dalam hubungan kasus konflik di Lampung, akulturasi budaya menjadi persoalan tersendiri. Akulturasi ${ }^{9}$ adalah perpaduan kebudayaan yang terjadi bila suatu kelompok manusia dengan suatu kebudayaan tertentu dihadapkan dengan unsur-unsur dari suatu kebudayaan asing yang berbeda, sehingga unsur-unsur kebudayaan asing itu dengan lambat laun diterima dan diolah kedalam kebudayaan sendiri, tanpa menghilangkan kepribadian kebudayaan sendiri. Ada juga yang menyatakan bahwa akulturasi budaya pada dasarnya merupakan pertemuan wahana atau area dua kebudayaan dan masing-masing dapat menerima nilai nilai bawaannya.

Di Lampung akulturasi budaya terjadi antara masyarakat suku asli Lampung dengan suku pendatang seperti Jawa, Bali, Minang, Batak dan lainnya. Kebudayaan Lampung yang menjadi adat istiadat masyarakat Lampung mulai tercampuri dengan adat istiadat lain. Dalam kehidupan masyarakat kota misalnya, akulturasi budaya sangat terjadi dimana para kelompok mudah membaur dengan melepaskan ego-komunalnya. Lain halnya pada masyarakat perbatasan antar suku yang cenderung mudah mengalami konflik. Misal saja konflik Balinuraga ${ }^{10}$ Lampung Selatan, Konflik Bumijawa Lampung Timur, Konflik Padang Ratu, Lampung Tengah ${ }^{11}$ dan konflik lainnya. Ali Humaedi

${ }^{6}$ Parekh, B, Rethinking Multiculturalism: Cultural diversity and Political Theory, (MacMillan: Press Ltd, 2000).

7 Frans Magnis Suseno, Melawan Kekerasan Tanpa Kekerasan, (Yogyakarta: PP Kesehatan Remaja Muhammadiyah, 2005), h. 179

8 Jamil Salmi, Violence and Demokratic Society, (Yogyakarta: Pilar Media, 2005), h. 32-40

${ }^{9}$ Koentjaraningrat, Pengantar Ilmu Antropologi. (Jakarta: Aksara Baru, 1980).h. 149

10 Bethra Ariestha, Akar Konflik Kerusuhan Antar Etnik Di Lampung Selatan (Studi Pada Kerusuhan Antar Etnik Lampung dan Etnik Bali di Lampung Selatan). Skripsi. Jurusan Psikologi Fakultas Ilmu Pendidikan Universitas Negeri Semarang (2013).

11 Putut Ary Sadewo, Dinamika Konflik Agraria dalam kehidupan sosial Masyarakat Sendangayu dan Surabaya Kecamatan Padangratu, (Tesis Pascasarjana Pendidikan IPS Fakultas Keguruan dan Ilmu Pendidikan Universitas Lampung, 2014).

| RI'AYAH, Vol. 02, No. 01 Januari-Juni 2017 
menyebut konflik Balinuraga sebagai kegagalan akulturasi budaya dan agama ${ }^{12}$ di etnis Lampung dan Bali. ${ }^{13}$

Komunitas Sekelik Sedulur adalah sebuah komunitas yang hadir di Lampung Tengah dalam rangka menangkal konflik etnis. ${ }^{14}$ Didirikan atas keprihatinan terhadap berbagai konflik bernuansa suku, agama, dan ras (SARA) yang terjadi di Lampung Tengah (Lamteng). Dalam kurun waktu beberapa tahun terakhir, konflik bernuansa SARA di Lamteng telah terjadi sebanyak 17 kali. ${ }^{15}$ Komunitas Sekelik Sedulur berusaha mengembalikan rasa damai, yang sesungguhnya menjadi falsafah luhur hidup orang Lampung dan Jawa. Menurut Kahfi,16 ada pemahaman masyarakat yang mulai bergeser. Sehingga pada gilirannya, pemahaman bersama tentang persaudaraan, kebangsaan, dan nilainilai persatuan diperlukan. Komunitas sekelik sedulur berusaha membangun kehidupan bersama, saling menghormati, dan semangat persaudaraan. ${ }^{17}$ Disamping berdiskusi, Komunitas Sekelik Sedulur juga aktif melalui media sosial, seperti Twitter, ${ }^{18}$ Facebook, maupun Instagram. Hadirnya Komunitas Sekelik Sedulur untuk mewujudkan semangat kebersamaan, agar tidak terjadi konflik di masa yang akan datang. ${ }^{19}$ Diplomasi kebudayaan menjadi salah satu jalan yang efektif. Munculnya komunitas itu menandakan bahwa anak-anak muda di Lampung Tengah memiliki wawasan dan gagasan yang sangat baik untuk menyatukan segala perbedaan yang ada khusunya di Bumi Beguwai Jejamo Wawai. ${ }^{20}$

\section{Metode Penelitian}

Penelitian ini adalah penelitian kualitatif dengan pendekatan etnografi yang mendayagunakan teori Intelektual kolektif Pierre Bourdieu dan akulturasi budaya Koentjaraningrat. Desain penelitian ini adalah penelitian kualitatif-deskriptif, yaitu sebuah penelitian yang berusaha mengungkap keadaan yang bersifat alamiah secara holistik. Penelitian kualitatif bukan hanya menggambarkan

\footnotetext{
12 M. Alie Humaedi, Kegagalan Akulturasi Budaya Dan Isu Agama Dalam Konflik Lampung, Jurnal “Analisa” Volume 21 Nomor 02 Desember 2014, halaman 149-162

${ }_{13}$ M. Alie Humaedi. Konflik Komunal Lampung-Bali: Anatomi dan Pemicu Konflik. Laporan Penelitian. (Jakarta: LIPI, 2013)

${ }^{14}$ http:// www.pojoksamber.com/komunitas-sekelik-sedulur-sebuah-ikhtiar-membangunpersaudaraan/ diunduh 21 Februari 2015.

15 http://www.pojoksamber.com/komunitas-sekelik-sedulur-sebuah-ikhtiarmembangun-persaudaraan/ diunduh 21 Februari 2015.

16 Wawancara Abdul Mukahfi, Koordinaor Komunitas Sekelik Sedulur (2/8/2015).

$17 \mathrm{http}: / /$ lampost.co/berita/anang-prihantoro-hadiri-dialog-kebudayaan-dan-pentas-seni diunduh 21 Februari 2015.

18 https://twitter.com/sekeliksedulur diunduh 21 Februari 2015

${ }^{19} \mathrm{http}: / /$ www.radarlamteng.co/?p=516 diunduh 21 Februari 2015

20 Sebutan untuk bumi Lampung Tengah yang artinya bekerja atau berbuat sesuatu untuk kepentingan masyarakat.
}

| RI'AYAH, Vol. 02, No. 01 Januari-Juni 2017 
variabel-variabel tunggal melainkan dapat mengungkap hubungan antara satu variabel dengan variabel lain. ${ }^{21}$

Populasi penelitian ini adalah Komunitas Sekelik Sedulur. Teknik sampling yang digunakan dalam penelitian ini adalah teknik purposif sampling, yaitu teknik mengambil sampel berdasarkan ciri-ciri populasi yang telah diketahui sebelumnya. Dalam penelitian ini menunjuk anggota populasi dengan dasar keyakinan bahwa anggota tertentu inilah yang paling tepat untuk dijadikan sampel dalam menggali dan mengungkap peran Komunitas Sekelik Sedulur dalam upaya membangun harmoni dan mencegak konflik etnis di Lampung Tengah. Adapun metode pengumpulan data dalam penelitian ini menggunakan Wawancara Semi Struktur (Semi Structured Questions) dan dokumentas.

Analisis data dilakukan dengan menggunakan langkah-langkah sebagai berikut: Pertama, pengumpulan data, yaitu kegiatan uantuk menemukan dan menghimpun sumber-sumber informasi yang relevan dengan penelitian. Kedua, interprestasi data, yaitu tahap penyusunan fakta dalam kerangka logis dan harmonis, sehingga menjadi kesatuan yang utuh. Kegiatan penyusunan ini disebut juga dengan proses sintesis atau interprestasi. Ketiga, penulisan, yaitu tahap ketika hasil interprestasi ditulis secara sistematis, logis, harmonis, dan konsisten, baik dari segi kata maupun alur pembahasan. Secara teoritik, analisis data adalah proses menyusun, mengkategori, mencari pola atau tema dari data yang ada dengan maksud untuk memahami maknanya. ${ }^{22}$ Dalam penelitian kualitatif ini, terdapat tiga komponen pokok yang akan dilalui peneliti, yaitu data reduction, data display, dan conclusion drawing.23 Tiga komponen analisis ini berlaku saling menjamin, baik sebelum, pada waktu, dan sesudah pelaksanaan pengumpulan data secara paralel yang disebut dengan model analisis mengalir (flow model of analysis).

\section{Komunitas Harmoni}

\section{Komunitas Intelektual Kolektif}

Dalam ilmu sosial terutama filsafat dan sosiologi, sering terjadi oposisi diantara subjektivisme dan objektivisme yang sering tidak terdamaikan. ${ }^{24}$ Dikotomi antara subjektivisme dan objektivisme tersebut meskipun terlihat bertentangan, namun pendekatan kedua perspektif ini diperlukan untuk menemukan hubungan saling mempengaruhi atau dialektika diantara keduanya. Keduanya saling terkait dan saling mempengaruhi dalam satu proses kompleks untuk menghasilkan praktik

${ }_{21}$ M. Sayuthi Ali, Metodologi Penelitian Agama; Pendekatan Teori dan Praktek, (Jakarta: PT Raja Grafindo Persada, 2002).

22 Lexy J. Moleong, Metode Penelitian Kualitatif, (Bandung: Remaja Karya, 1989), h. 4-8

23 Heribertus Sutopo, Pengantar Penelitian Kualitatif: Dasar-Dasar Teoritis dan Praktis, (Surakarta: Puslit UMS, 1988), h. 34.

24 Pierre Bourdieu, The Logic of Practice, (Stanford: Stanford University Press, 1992), h. 25.

| RI'AYAH, Vol. 02, No. 01 Januari-Juni 2017 
sosial.25 Praktik sosial tidak hanya meletakkan subjek pada peran utama pembentukan dunia, melainkan juga memperhitungkan konteks ruang dan waktu yang melatarbelakanginya. ${ }^{26}$ Maka untuk dapat mendialektikakan keduanya, Bourdieu merumuskan konsep habitus, arena, dan modal. Ketiga konsep ini berada dalam satu bingkai yang dinamai Bourdieu dengan strukturalisme genetik. ${ }^{27}$

Konsep habitus, arena, dan modal ini merupakan rumusan generatif dari teori Bourdieu tentang bagaimana praktik sosial berjalan. Habitus merupakan hasil keterampilan yang menjadi tindakan praktis (tidak selalu disadari) yang diterjemahkan menjadi kemampuan yang terlihat alamiah. Sebagai hasil dari ketrampilan individu yang menubuh, habitus tidaklah seragam karena ia beroperasi dalam suatu ruang sosial atau arena tertentu yang kemudian mempengaruhi rutinitas tindakannya. ${ }^{28}$ Arena merupakan ruang yang terstruktur dengan aturan keberfungsiannya yang khas namun tidak secara kaku terpisah dari arena-arena lainnya dalam sebuah dunia sosial. Arena membentuk habitus yang sesuai dengan struktur dan cara kerjanya, namun habitus juga membentuk dan mengubah arena sesuai dengan strukturnya. Otonomisasi relatif arena ini mensyaratkan agen yang menempati berbagai posisi yang tersedia dalam arena apapun, terlibat dalam usaha perjuangan memperebutkan sumber daya atau modal yang diperlukan guna memperoleh akses terhadap kekuasaan dan memperoleh posisinya dalam arena tersebut. ${ }^{29}$

\section{Harmoni Agama}

Harmoni (kerukunan) umat beragama adalah keadaan hubungan sesama umat beragama yang dilandasi toleransi, saling pengertian, saling menghormati, menghargai kesetaraan dalam pengamalan ajaran agamanya dan kerjasama dalam kehidupan bermasyarakat, berbangsa dan bernegara di dalam Negara Kesatuan Republik Indonesia berdasarkan Pancasila dan Undang-Undang Dasar Negara Republik Indonesia Tahun 1945 (PBM No. 9 dan 8 Tahun 2006 Bab I pasal 1). ${ }^{30}$

25 Bagus Takwin, Proyek Intelektual Pierre Bourdieu: Melacak Asal-Usul Masyarakat, Melampaui Oposisi Biner dalam Masyarakat, dalam: Harker dkk (ed), (Habitus x Modal) + Ranah = Praktik,(Yogyakarta: Jalasutra, 2005), h. xvii.

${ }^{26}$ Suma Riella Rusdiarti, Bahasa, Pertarungan Simbolik dan Kekuasaan, dalam (Basis No. 1112, Th. 52, November-Desember 2003), h. 33

27 Pierre Bourdieu, Arena Produksi Kultural, (Yogyakarta: Kreasi Wacana, 2010), h. xiii.

${ }^{28}$ Haryatmoko, Sekolah, Alat Reproduksi Kesenjangan Sosial, dalam (Basis, No. 07-08, Tahun ke-57,2008), h. 16

67.

${ }^{29}$ Arizal Mutahir, Intelektual Kolektif Pierre Bourdieu, (Yogyakarta: Kreasi Wacana, 2011), h.

30 Haidlor Ali Ahmad, "Umat Beragama di Kabupaten Kediri: Antara Harmoni dan Konflik", dalam Jurnal Harmoni, Puslitbang Kehidupan Keagamaan Badan Litbang \& Diklat Kementerian Agama RI, Volume X, Nomor 2, April - Juni 2011

| RI'AYAH, Vol. 02, No. 01 Januari-Juni 2017 
Secara teoritik, semua agama mengajarkan kebaikan dan dipraktikkan sebagai ekspresi perilaku ketuhanan. ${ }^{31}$ Ini titik-titik konseptual, tetapi dalam kenyataannya ada potensi konflik luar biasa hebat. Ada kandungan "perintah" untuk bersikap eksklusif terhadap agama lainnya dan juga sikapsikap pembenaran atas agamanya sendiri (truth claim). ${ }^{32}$ Potensi ini dalam sejarah kehidupan beragama di Tanah Air mengalami pasang-surut dan, dalam batas-batas tertentu, telah menyajikan realitas konflik yang bersifat laten.

Itulah sebabnya, usaha untuk terus melakukan dialog antar iman dan penyuluhan tentang kerukunan antar dan intra umat beragama perlu terus dilakukan. Ada tuntutan agar paradigma penyajian ajaran-ajaran agama tidak dilakukan secara radikal, eksklusif, kaku, dan dogmatis. Sebaliknya ia harus disajikan secara cerdas, beradab, universal, cair, kritis, dan memerhatikan etika umum umat manusia.

Di sini, peran kaum elit agama perlu diarahkan pada pembangunan harmoni antar iman. Mereka juga dituntut untuk selalu meningkatkan kapasitas moral, intelektual, dan kapasitas wawasan sosio-kultural modern agar mampu menempatkan ajaran agama tidak dalam kerangka konfliktual dan jatuh ke dalam teori konspirasi (yakni teori yang sudah dipatok bahwa kami selalu benar dan mereka selalu salah). Hubungan antar suku di Lampung misalnya harus keluar dari teori konspirasi merasa benar sendiri.

Menempatkan ajaran agama dalam bingkai harmoni antar iman merupakan kecenderungan abad ini yang sangat menjanjikan. Sejarah konflik antar agama di awal perkembangannya, sejatinya, merupakan sisi gelap agama yang sudah menjadi masa lalu. Abad-abad mendatang telah diyakini sebagai abad harmoni agama-agama. Hal ini terjadi karena abad informasi telah memungkinkan semua agama saling berbagi tentang banyak hal. Selain itu, ada masalah-masalah bersama yang telah mengancam semua umat manusia seperti krisis lingkungan, ancaman perang nuklir, terorisme, krisis pangan, krisis energi, dan lain sebagainya. Kesalingpengertian antar iman yang di peluk umat manusia telah menyadarkan akan makna kebersamaan, saling menolong, saling menghormati, dan saling peduli. Kecenderungan semacam ini merupakan kenyataan yang sangat menggembirakan. Tetapi persoalannya, kenyataan ini tidak merata di seluruh bangsa di dunia. Ada sejumlah bangsa yang masih didera oleh konflik-konflik antar agama.

31 Lihat sebagai perbandingan Frithjop Schuon, The Transcendent Unity of Religions (New York, London: Harper and Row Publisher, 1975).

32 Frans Magnis Suseno menyatakan bahwa konflik antar agama bukan terutama disebabkan oleh dogma agama tetapi oleh perpecahan atau fragmentasi masyarakat Indonesia. Dalam pandangan saya, pendapat Magnis Suseno kurang tepat. Karena, perpecahan masyarakat bisa juga dating dari perpecahan agama, misalnya, karena pelecehan oleh penganut agama lain. Baca tulisan Frans Magnis Suseno, "Kerukunan Beragama dalam Keragaman Agama” dalam Alef Theria Wasim dkk. (ed.), Harmoni Kehidupan Beragama: problem, praktek dan pendidikan, (Yogyakarta: Oasis Publisher, 2005), h. 1-21

| RI'AYAH, Vol. 02, No. 01 Januari-Juni 2017 
Dalam konteks Indonesia, potensi konflik masih tetap berbahaya. Meski, dalam batas-batas tertentu, kerukunan dan integrasi sikap keagamaan telah membaik, namun tetap saja diperlukan sikap waspada. Seperti bom waktu, konflik antar agama di sini bisa setiap saat muncul bila ada pemicunya. Apa yang terjadi selama ini dalam konflik suku memang mengalami hambatan yaitu sulit mendeteksi potensi konflik yang akan terjadi.

Ajaran-ajaran agama mengartikulasikan ideal-ideal yang tidak seluruhnya dapat operasionalkan dalam kehidupan. Sebabnya adalah kenyataan-kenyataan sosial jauh lebih kompleks. Realitas sosial berkaitkelindan dengan pelbagai kepentingan dan pelbagai kenyataan lain yang dikendalikan oleh banyak aktor. Agar pelbagai kenyataan dan faktor sosiobudaya tadi tidak saling bertabrakan dengan ideal-ideal agama, maka diperlukan suatu kecanggihan penafsiran ajaran. Kecanggihan penafsiran itu diarahkan untuk menemukan titik-titik temu yang oleh Hans Kung disebut common values. ${ }^{33}$ Dan oleh Nurcohlish Madjid disebut kalimatun sawa. ${ }^{34}$

Di sini peran ulama sangat diperlukan guna memberi tafsir-tafsir keagamaan yang lebih inklusif, berwawasan universal, dan berpihak pada nilai-nilai kemanusiaan. Para ulama atau elit agama harus membaca Kitab Suci dari perspektif yang lebih cerdas dan mencerahkan. Mereka tidak terperangkap dalam sikap eksklusif yang menempatkan diri mereka sebagai juru bicara Tuhan.35 Dengan demikian, mereka tidak secara otoriter menggunakan agama sebagai instrumen penundukan atau dominasi atas yang lainnya (the others).

\section{Harmoni dalam Multikultural}

Hal yang berbeda antara pandangan masyarakat majemuk (pluralisme) dengan multikulturalisme. Sebagaimana Furnival menggambarkan tentang konsep masyarakat majemuk (pluralisme), ia menggambarkan bahwa masyarakat yang hidup secara rasial atas komunitas-komunitas yang berbeda hidup berdampingan, tetapi terpisah dalam satuan yang sama. ${ }^{36}$ Layaknya dalam pandangan budaya ekonomi, masyarakat yang beragam dengan kepentingan masing-masing dan hanya bertemu dengan kepentingan di pasar, setelah itu terpisah dan kembali dalam komunitasnya. Menurut Achmad, kebudayaan masyarakat majemuk dilihat sebagai entitas otonom, distinktif, yang memiliki diferinsiasi. Dan batas antara kebudayaan satu sama lain terlihat terang namun sama dalam

${ }^{33}$ Lihat Hans Kung, "Sebuah Model Dialog Kristen dan Islam" dalam Jurnal Pemikiran Islam Paramadina, Vol. 1, Nomor 1, Juli-Desember 1998, h. 9-32.

${ }^{34}$ Nurcholish Madjid, Islam, Doktrin dan Peradaban: Sebuah Telaah Kritis tentang Masalah Keimanan, Kemanusiaan, dan Kemodernan, (Jakarta: Pramadina, 1992), cet. I.

35 Lihat Mudhofir Abdullah, Jihad Tanpa Kekerasan (Jakarta: Inti Medina, 2009), h. 7-9

${ }^{36}$ Achmad Fedyani Syaifudin, "Membumikan Multikulturalisme di Indonesia" Jurnal Antropologi Sosial Budaya ETNOVISI, (Jakarta; UI, 2006) Vol II/No I, h. 4

| RI'AYAH, Vol. 02, No. 01 Januari-Juni 2017 
kepentingan di arena pasar atau ruang publik dalam kepentingan tertentu. ${ }^{37}$ Lampung memiliki karakteristik yang majemuk, yaitu beragamnya suku dan agama yang mendiami bumi Lampung.

Sedangkan multikulturalisme, dibangun atas kepercayaan yang utuh atas entitas komunitas yang ada walau hanya secara minoritas, dan tentu saling mendorong untuk hadir bersama di dalam ruang publik dalam kerangka bingkai masing-masing. Keterlibatan satu sama lain dalam praktik sosial ialah ciri dari aplikasi multikultural. Seperti ungkapan Heywood tentang multikulturalisme secara normatif. "As a normative term, multiculturalism implies a positive of communal diversity, based upon the right of different cultural grups to recognition and respect. In this sense, it acknowledges the importance of beliefs, values and ways of life in establishing a sense of self-worth for individuals and grups alike. ${ }^{38}$ Dalam pandanganya, dukungan positif untuk keragaman yang ada adalah penting dalam mengikat kepercayaan satu sama lain. Dengan begitu komunitas lain atau perbedaan segemen komunitas saling dukung mendukung menciptakan keharmonisan. Senada dengan James A. Banks yang dikutip oleh Rose Reissman, “...Multicultural education promotes the freedom, abilities and skills to cross ethnic and cultural boundaries to participation in other cultures and grups. ${ }^{39}$ Pendidikan multikultural menjadikan dasar tindakan saling memajukan satu sama lain. Promotes di dalam pendapat Banks dipahami sebagai tindakan praktis, tidak berhenti dalam penghargan perbedaan. ${ }^{40}$

Pendidikan multikultural (multicultural education) merupakan sebuah gerakan pembaharuan yang mengubah semua komponen pendidikan termasuk mengubah nilai-nilai dasar pendidikan, aturan prosedur, kurikulum, materi pengajaran, struktur organisasi dan kebijakan pemerintah yang merefleksikan pluralisme budaya. Multicultural education hakaketnya juga merupakan upaya melembagakan filsafat pluralisme budaya dalam sistem pendidikan dengan membumikan prinsip persamaan, saling menghargai, menerima dan memahami serta adanya komitmen moral terhadap keadilan sosial. ${ }^{41}$

\section{Harmoni antar Etnis atau budaya}

Istilah etnis mengacu pada suatu kelompok yang sangat fanatik dengan ideologi kelompoknya dan tidak mau tahu dengan ideologi kelompok lain. Dalam perkembangannya makna ethnos berubah menjadi etnichos yang secara harfiah digunakan untuk menerangkan keberadaan

37 Ibid., h. 4

${ }^{38}$ Heywood, Andrew. Political Ideologies (3th Edition). (Palgrave: McMillan, 2007). h. 53

39 Zubaedi "Telaah Konsep Multikulturalisme., h. 8

40 Terjemahan di oxford.

41 Geneva Gay, "A Synthesis of Scholarship in Multicultural Education" dalam Urban Education Monograph Series, (Washington, NCREL's Urban Education Program, 1994), h. 2

| RI'AYAH, Vol. 02, No. 01 Januari-Juni 2017 
sekelompok "penyembah berhala" atau orang kafir yang hanya berurusan dengan kelompoknya sendiri tanpa peduli kelompok lain. ${ }^{42}$

Menurut Narroll yang dikutip Ali Liliweri kelompok etnis dikenal sebagai suatu populasi yang:43 a) Secara biologis mampu berkembang-biak dan bertahan. b) Mempunyai nilai-nilai budaya yang sama dan sadar akan rasa kebersamaan dalam bentuk budaya. c) Membentuk jaringan komunikasi dan interaksi sendiri, dan d) Menentukan ciri kelompoknya sendiri yang diterima oleh kelompok lain dan dapat dibedakan dari kelompok populasi lain.

Pendapat lain tentang etnis dikemukakan oleh Fredrick Barth dan Zatrow yang mengatakan bahwa etnis adalah himpunan manusia karena kesamaan ras, agama, asal-usul bangsa ataupun kombinasi dari kategori tersebut yang terikat pada sistem nilai budayanya. Sementara Koentjaraningrat ${ }^{44}$ memaknai etnis sebagai kelompok sosial atau kesatuan hidup manusia yang mempunyai sistem interaksi, sistem norma yang mengatur interaksi tersebut. Adanya kontinuitas dan rasa identitas yang mempersatukan semua anggotanya serta memiliki sistem kepemimpinan sendiri.

Konsep kebudayaan menurut Koentjaraningrat dalam konsep kebudayaan diartikan sebagai wujudnya, yaitu mencakup keseluruhan dari: (1) gagasan; (2) kelakuan; dan (3) hasil-hasil kelakuan. Dengan menggunakan definisi ini maka seseorang pengamat atau peneliti akan melihat bahwa segala sesuatu yang ada dalam pikirannya, yang dilakukan dan yang dihasilkan oleh kelakuan atau perilaku manusia adalah kebudayaan. ${ }^{45}$

Warisan budaya, menurut Davidson (1991) diartikan sebagai 'produk atau akibat budaya fisik dari tradisi-tradisi yang berbeda dan prestasiprestasi spiritual dalam bentuk nilai dari masa lalu yang menjadi elemen dasar dalam jati diri suatu kelompok atau bangsa'. Jadi warisan budaya merupakan akibat budaya fisik (tangible) dan nilai budaya (intangible) dari masa lalu. ${ }^{46}$ Nilai budaya dari masa lalu (intangible heritage) inilah yang berasal dari budaya-budaya lokal yang ada di Nusantara, meliputi: tradisi, cerita rakyat dan legenda, bahasa ibu, sejarah lisan, kreativitas (tari, lagu, drama pertunjukan), kemampuan beradaptasi dan keunikan masyarakat setempat. 47

Nilai-nilai budaya asli tentang persatuan dan kesatuan sebenarnya telah dimiliki dan dijunjung tinggi oleh masing-masing suku bangsa di

${ }^{42}$ Liliweri, Op.Cit., hal. 8-9.

43 Ibid., hal. 9.

44 ibid

${ }^{45}$ Koentjaraningrat, Ilmu Antropologi. (Jakarta: Bhratara, 1988)

${ }^{46}$ Davison, G. dan C Mc Conville. A Heritage Handbook. St. Leonard, (NSW: Allen, \& Unwin, 1992), h. 2

${ }^{47}$ Galla, A. Guidebook for the Participation of Young People in Heritage Conservation. (Brisbane: Hall and jones Advertising, 2001) h.12

| RI'AYAH, Vol. 02, No. 01 Januari-Juni 2017 
Indonesia. Kondisi seperti ini dibuktikan dengan keadaan yang damai, tenteram dan hubungan yang harmonis diantara suku bangsa pada masa lalu. Keadaan baru berubah, ketika penjajah datang di bumi nusantara ini. Nilai-nilai kerukunan, persatuan dan kesatuan cenderung dikaburkan agar bangsa Indonesia terpecah belah, lemah dan mudah dijajah. Politik yang sangat terkenal yang digunakan penjajah adalah 'Politik De Vide et Impera'48.

\section{Akulturasi Budaya}

Kamus Besar Bahasa Indonesia (1989), istilah akulturasi diartikan sebagai penyerapan yang terjadi oleh seorang individu atau sekelompok masyarakat, terhadap beberapa sifat tertentu dari kebudayaan kelompok lain sebagai akibat dari kontak atau interaksi dari kedua kelompok kebudayaan tersebut, sedangkan akulturasi budaya diartikan sebagai hasil interaksi manusia berupa pencampuran dari beberapa macam kebudayaan secara perlahan menuju bentuk budaya baru.

Dari definisi diatas, maka dapat disimpulkan bahwa akulturasi sama dengan kontak budaya yaitu bertemunya dua kebudayaan yang berbeda dan melebur menjadi satu, sehingga menghasilkan adanya kontak kebudayaan baru atau sebuah akulturasi yang menghasilkan bentuk-bentuk kebudayaan baru dan tidak melenyapkan kebudayaan aslinya.

Pengertian tentang akulturasi, Koentjaraningrat juga mengemukakan bahwa: Akulturasi adalah proses sosial yang timbul bila suatu kelompok manusia dengan suatu kebudayaan tertentu dihadapkan dengan unsur-unsur dari suatu kebudayaan asing dengan sedemikian rupa, sehingga unsur-unsur kebudayaan asing tersebut lambat laun diterima dan diolah kedalam kebudayaan sendiri tanpa menyebabkan hilangnya kepribadian budaya itu sendiri. ${ }^{49}$

J. Powel juga mengungkapkan bahwa akulturasi dapat diartikan sebagai masuknya nilai-nilai budaya asing ke dalam budaya lokal tradisional. Budaya yang berbeda itu bertemu, yang luar mempengaruhi yang telah mapan untuk menuju suatu keseimbangan. ${ }^{50}$ Perhatian terhadap saluran-saluran yang dilalui oleh unsur-unsur kebudayaan asing untuk masuk kedalam kebudayaan penerima, akan memberikan suatu gambaran yang konkret tentang jalannya suatu proses akulturasi. ${ }^{51}$

Proses dari wujud akulturasi kebudayaan, terjadi ketika beberapa kebudayaan saling berhubungan secara intensif dalam jangka waktu yang cukup lama, kemudian masing-masing dari kebudayaan tersebut berubah saling menyesuaikan diri menjadi satu kebudayaan. Hasil dari

\footnotetext{
hlm. 115

50 J.W.M. Bakker SJ, Filsafat Kebudayaan Sebuah Pengantar (Yogyakarta: Kanisius, 1984),

51 Ibid., h. 253-254
} 1990) h. 253-254.

48 Politik pecah belah atau politik adu domba

49 Koentjaraningrat, Pengantar Ilmu Antropologi, (Jakarta: Universitas Indonesia Press,

| RI'AYAH, Vol. 02, No. 01 Januari-Juni 2017 
proses wujud akulturasi kebudayaan tersebut, dapat dilihat pada Bahasa, Religi dan Kepercayaan, Organisasi Sosial Kemasyarakatan, Sistem Penge tahuan, Kesenian dan Bentuk Bangunan. Bentuk dari perwujudan akulturasi budaya, merupakan salah satu hasil aktivitas manusia Struktur masyarakat Indonesia yang majemuk (multietnik), selalu menimbulkan perpaduan antara kebudayaan inti (kebudayaan asli) dengan kebudayaan luar lainnya. Konsep melting pot (tempat bertemunya berbagai suku, agama dan tempat persinggahan antar bangsa) merupakan salah satu hasil dari sebuah wujud akulturasi budaya, ketika unsur-unsur kebudayaan saling bertemu dan melebur menjadi satu kebudayaan. Proses perubahan kebudayaan tersebut terjadi dikarenakan adanya kontak langsung terus menerus dengan kebudayaan asing yang berbeda (ada unsur kebudayaan asing yang mudah diterima, ada juga yang sukar diterima bahkan ditolak).

\section{Pembahasan}

Sekelik Sedulur merupakan suatu komunitas yang lahir dari sebuah gagasan sebagai bentuk kepedulian terhadap lingkungan, dengan harapan agar tercipta suasana yang damai, aman, sejahtera di Lampung Tengah khususnya, dan di propinsi Lampung pada umumnya. Komunitas ini menghimpun diri dari setiap suku, etnis, ras, dan agama, tidak hanya terbatas untuk orang Lampung dan Jawa saja penggiatnya, tapi juga membuka diri untuk masyarakat yang ingin bergabung. Untuk mencapai harapan tersebut tentu dukungan dari semua pihak dan golongan diperlukan tanpa memandang perbedaan.

Dengan visi melestarikan budaya lama yang baik dan mengambil budaya baru yang lebih baik, dan Misi menjalin persaudaraan dan menjaga kerukunan ditengah keberagaman. Semoga Sekelik Sedulur senantiasa terikat erat sehingga suasana kondusif khususnya di Kabupaten Lampung Tengah dan umumnya di Provinsi Lampung terus terpelihara. Berasas Pancasila dan UUD 45 dengan semboyan gotong royong, dan berpaham nasionalis, Sekelik Sedulur diharapkan dapat mampu menjadi wadah yang kokoh untuk menjalin silaturahmi antara individu satu dengan yang lainnya dengan beragam latar belakang, dan menjadi simbol perdamaian di Provinsi Lampung.

\section{Kampanye Persaudaraan}

Kondisi konflik di Indonesia saat ini masih terus mewarnai berbagai media masa, baik konflik yang sifatnya kecil ataupun besar dengan berbagai macam latar belakang permasalahan. Demikian pula di Lampung, sebagai provinsi yang berada di ujung pulau sumatra ini memang memiliki keunikan tersendiri jika dibandingkan dengan provinsi-provinsi yang lain di sumatra. Sebagai provinsi yang ditempati oleh berbagai macam suku menjadikan kecenderungan terjadinya konflik semakin tinggi. Misalnya, di Lampung Tengah telah terjadi lebih dari 17 kali konflik dalam kurun waktu tujuh tahun terakhir. Dari permasalahan yang kerap kali terjadi tersebut dalam hal ini 
komunitas sekelik sedulur melakukan gerakan intelektual kolektif sebagai upaya dalam membangun akulturasi budaya khususnya pada suku lampung dan jawa di lampung tengah. Adapun salah satu usaha yang dibangun adalah kempanye persaudaraan dengan melalui berbagai macam media seperti halnya kampanye di lembaga pendidikan mulai dari sekolah-sekolah hingga perguruan tinggi, memasang stiker di rumah-rumah maupun kendaraan roda dua dan empat, pemasangan baliho dan spanduk di jalan umum, kampanye malalui media sosial youtube, facebook, twitter, website, koran cetak dan online.

\section{Gambar 1. Foto Kampanye Sekelik Sedulur di Madrasah Aliyah Ma'arif Bandar Jaya Lampung Tengah}

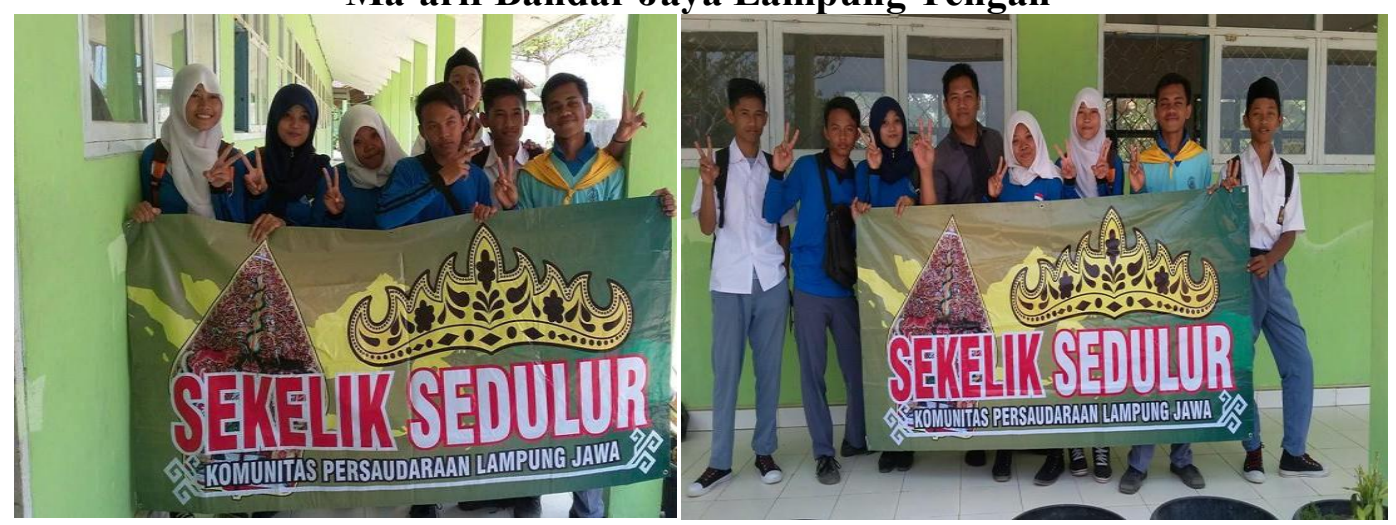

Sumber Foto: Dokumentasi Sekelik Sedulur

\section{Merawat nilai-nilai Lampung dan Jawa}

Masyarakat Lampung mempunyai falsafah Sang Bumi Ruwa Jurai, yang artinya sebuah rumah tangga dari dua garis keturunan, masing-masing melahirkan masyarakat beradat pepadun dan masyarakat beradat sebatin. Sekarang, pengertian Sang Bumi Ruwa Jurai diperluas menjadi masyarakat Lampung asli (suku Lampung) dan masyarakat Lampung pendatang (sukusuku lain yang tinggal di Lampung). Nenek moyang orang Lampung menurut legenda adalah Puyang Mena Tepik di negeri Sekalabrak. Daerah ini dinamai Lampung karena jika dilihat dari laut seperti bukit yang mengapung. Masyarakat Lampung memiliki kearifan lokal berupa falsafah hidup fil pesenggiri. Pill pesenggiri mengandung pandangan hidup masyarakat yang diletakan sebagi pedoman dalam tata pergaulan untuk memelihara kerukunan, kesejahtraan dan keadilan. Pill Pesenggiri memiliki makna sebagai harga diri, jati diri atau martabat. seseorang yang memiliki pill pesenggiri yang kuat berarti memiliki perasaan penuh keyakinan, penuh tanggung jawab, kompeten dan sanggup mengatasi masalah-masalah hidup. Piil pesenggiri itu didukung unsur-unsurnya yakni Bejuluk-beadek, Nemuinyimah, Nengah-nyappur, dan Sakai-samabayan. 


\section{Gambar 2 Menara Siger, Mahkota Keagungan Adat Lampung}

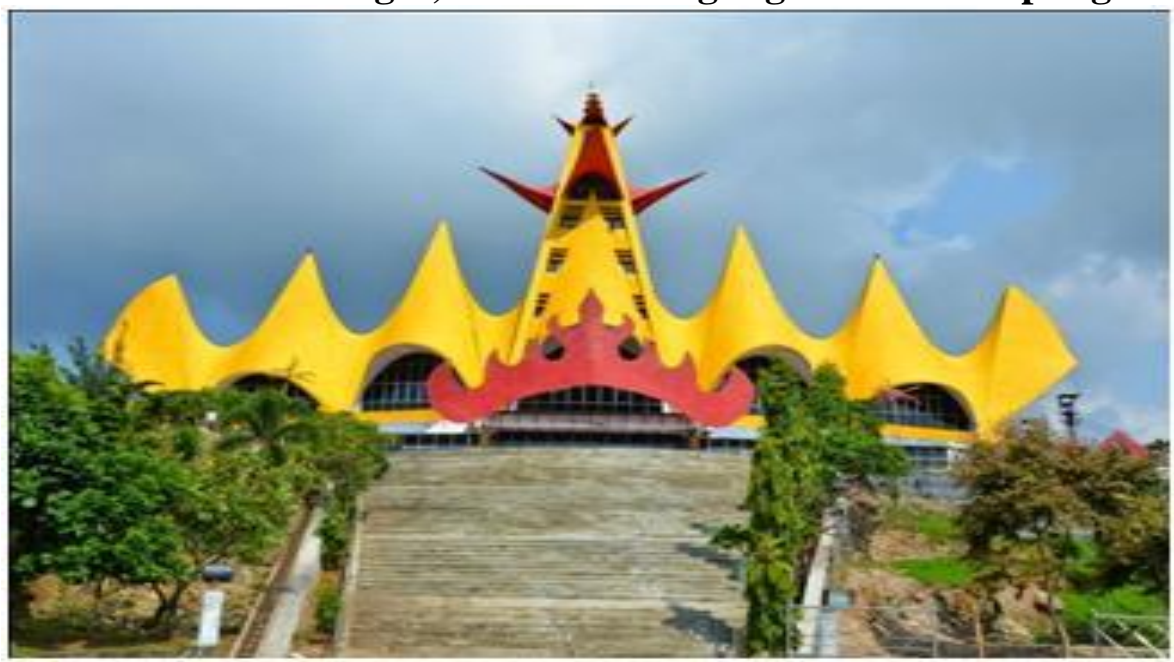

Sumber. Kenny chandra (2015)

Bejuluk-beadek dalam arti harfiah Bejuluk nama yang diberikan kepada seseorang sebagai nama kasih sayang keluarga, Beadek nama yang diberikan kepada seseorang setelah ia memikul tanggung jawab. Bejuluk, beinai, beadek adalah implementasi dari sebuah nama yang melekat pada diri seseorang yang memiliki harga diri, jati diri dan martabat, oleh karenanya nama itu harus dijaga dari tingkah laku yang tercela. Bahasa yang santun, pribadi yang mempesona, bertanggung jawab terhadap beban yang diamanahkan melalui juluk, adek, dan enai yang berikan kepada seseorang selalu menjaga nama itu sehingga tidak terkena sanksi adat berupa cepalo atau sanksi lainnya yang berakibat kepada keluarga besarnya. Dalam merawat nilai Bejuluk beadek maka dalam hal ini sekelik sedulur menjalin komunikasi dengan berbagai kalangan tokoh adat untuk mengajak elemen masyarakat dalam melestarikan nilai tersebut melalui kegiatan resepsi pernikahan setiap anak-anak dari kalangan masyarakat sebagai wujud implementatif merawat dan menumbuhkan nilai-nilai piil pesenggiri.

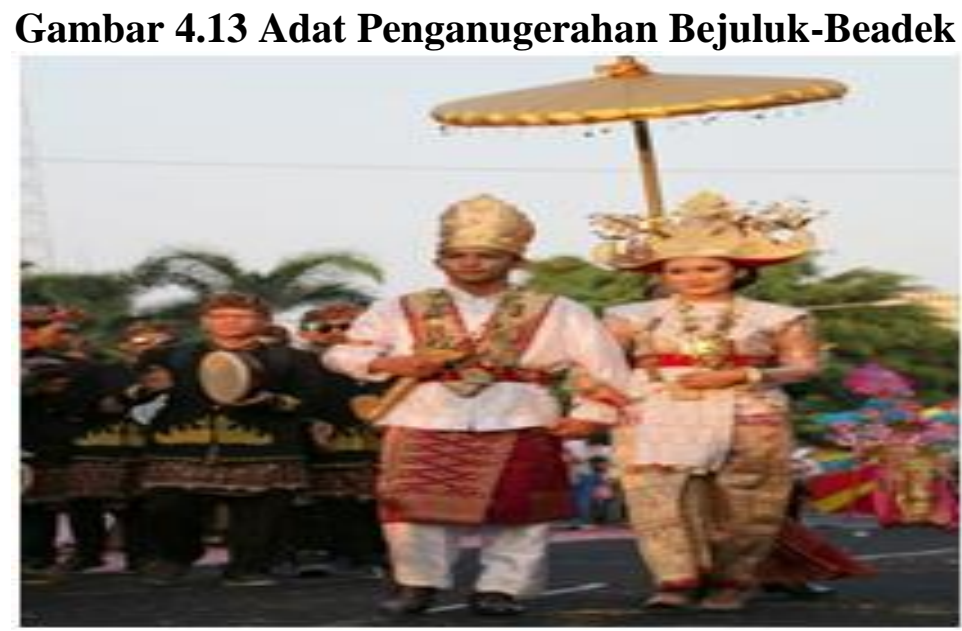

Sumber. Dokumentasi hazi-mvp (2011)

| RI'AYAH, Vol. 02, No. 01 Januari-Juni 2017 
Nemui-nyimah kata nemui yang berarti tamu dan nyimah yang berasal dari kata simah yang berati santun. masalah "tamu" atau "pertemuan" dimaksudkan sebagai eksistensi seseorang. orang dikatakan berhasil, jika sanggup menjadi tamu yang baik atau bisa menjadi tuan rumah yang bisa menerima tamu. Apapun posisinya baik sebagai tamu maupun tuan rumah, maka yang menjadi ukurannya adalah "simah" yang berarti santun. Jadi sikap santun menjadi eksistensi seseorang dalam komunitas masyarakat lampung. kesantunan seseorang itu bisa dalam bentuk perilaku, tutur kata, dan juga dalam bentuk benda. Sehingga dalam hal ini komunitas sekelik sedulur menjadikan nemuy nyimah sebagai cara yang amat efektif dalam membangun sekelik sedulur. Dengan adanya nemuy nyimah tersebut maka menjadi sebuah alat komunikasi yang baik sehingga segala sesuatu permasalahan yang hadir ditengah-tengah masyarakat akan lebih mudah dicarikan titik temunya.

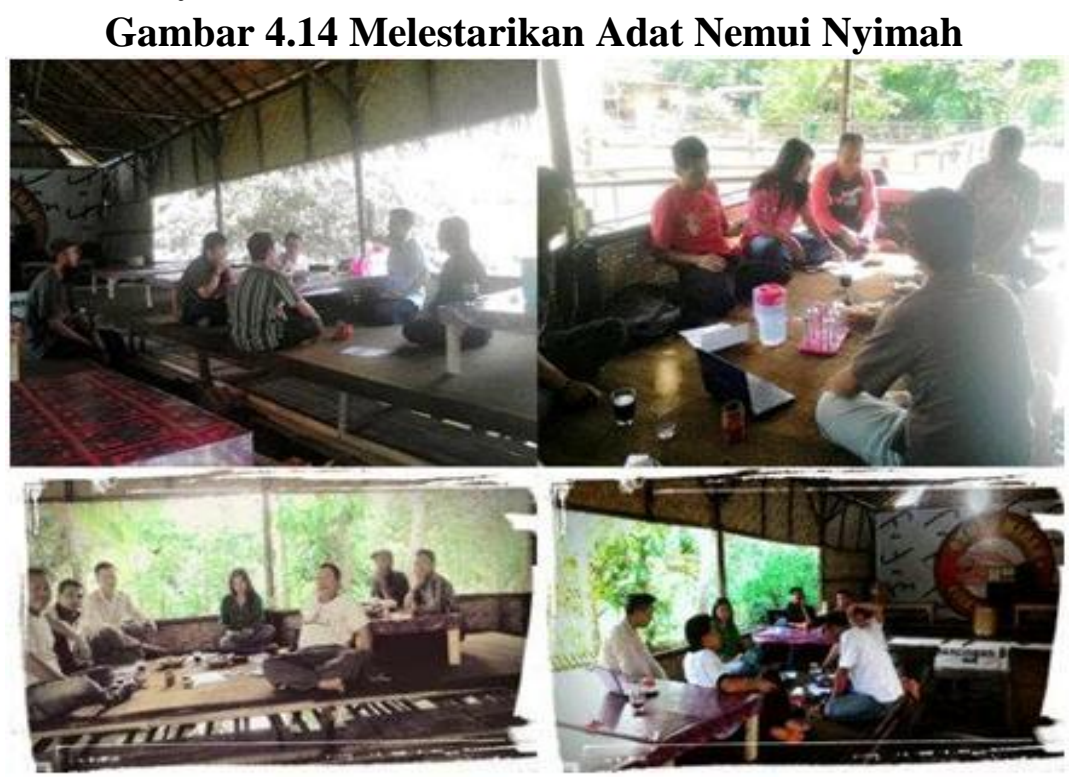

Sumber: Gamolan Institut (2015)

Nengah-nyappur, Nengah Nyappur ini juga merupakan salah satu upaya masyarakat lampung untuk membekali diri baik dari sisi intelektual maupun spiritual, sehingga memiliki kemampuan dalam mengorganisir isi alam untuk kemudian dimanfaat kan secara optimal bagi kemakmuran masyarakat. Maka dalam hal ini Nengah-nyappur menggambarkan bahwa anggota masyarakat Lampung mengutamakan rasa kekeluargaan dan didukung dengan sikap suka bergaul dan bersahabat dengan siapa saja, tidak membedakan suku, agama, tingkatan, asal usul dan golongan.

Sakai sambaiyan berarti tolong menolong dan gotong royong, artinya memahami makna kebersamaan atau guyub. Sakai-sambayan pada hakekatnya adalah menunjukkan rasa partisipasi serta solidaritas yang tinggi 
terhadap berbagai kegiatan pribadi dan sosial kemasyarakatan pada umumnya. Sebagai masyarakat Lampung akan merasa kurang terpandang bila ia tidak mampu berpartisipasi dalam suatu kegiatan kemasyarakatan. Perilaku ini menggambarkan sikap toleransi kebersamaan, sehingga seseorang akan memberikan apa saja secara suka rela apabila pemberian itu memiliki nilai manfaat bagi orang atau anggota masyarakat lain yang membutuhkan.

Ketika Lampung memililiki sang bumi ruwa jurai dan siger sebagai salah satu falsafah kehidupanya, maka jawa juga memiliki falsafah gunungan wayang sebagai media kearifan lokalnya. Wayang gunungan atau yang sering disebut dengan kekayon berasal dari kata kayu artinya pohon. Kekayon diartikan sebagai pohon hidup atau pohon hayat.

Gunungan (kayon) dalam pewayangan memiliki berbagai macam lambang dimana setiap lambang memiliki tentu makna masing-masing seperti halnya gunung, pohon besar, api, ombak, samudra, angin ribut, gua dan lain-lain. Kekayon sebenarnya melambangkan filosofis kehidupan orang jawa, karena gunungan wayang membawakan lambang konsep mitos Jawa: Sangkan Paraning Dumadi. Gunungan adalah pahatan lukisan berbentuk gunung (dalam wayang golek atau kulit) untuk mengawali, membatasi antara babak dan mengahiri cerita.

Dalam memahami merawat dan membumikan nilai-nilai falsafah kedua suku lampung dan jawa ini, komunitas sekelik sedulur merawat melalui berbagai macam usaha seperti melakukan dialog kebudayaan, penanaman pohon, silaturahim tokoh, silaturahim dan rembug warga lampung dan jawa, refleksi kemerdekaan, pentas seni dan dialog kebudayaan lampung dan jawa, dan lain sebagainya.

\section{Gerakan Pemuda Lampung dan Jawa}

Dalam agendanya pemuda lampung dan jawa memiliki berbagai macam kegiatan sebagai wadah dalam melestarikan nilai-nilai lampung dan jawa sekaligus sebagai gerakan intelektual kolektif dalam membangun rasa harmoni anatar kedua suku. Adapan gerakan yang dilakukan oleh pemuda komunitas sekelik sedulur adalah:

Pertama, Dialog kebudayaan. Seringkali permasalahan yang timbul antar suku terjadi akibat kurang saling mengenal satu sama lain. Intensitas pertemuan yang minim untuk berdialog bersama membuat kekurang pahaman ini terus terjadi sehingga muncul stereotip terhadap suku yang berbeda. Streotip ini kemudian berdampak terhadap perilaku suku lain yang sudah terstereotip tersebut. Akibatnya orang akan sangat mudah menjustifikasi orang lain dengan sesuatu yang negatif dan akhirnya muncul kebencian satu sama lain. Untuk merespon permasalahan miskomunikasi dan misunderstanding ini, Komunitas Sekelik Sedulur mengadakan dialog kebudayaan antara suku Jawa dan Lampung. Pemahaman yang 
komprehensif terhadap budaya suku lain dapat melahirkan efek positif terhadap hubungan sosial. Karena sejatinya kebudayaan merupakan sesuatu yang mengandung banyak nilai kebaikan. Selama satu tahun berdiri, komunitas Sekelik Sedulur mencoba menunjukkan kontribusinya dengan melaksanakan berbagai kegiatan positif salah satunya adalah dialog kebudayaan yang diadakan diberbagai tempat di Lampung Tengah dan beberapa kabupaten lain. Adapun dialog yang dibangun oleh komunita sekelik sedulur adalah dialog kebudayaan siger dan gunungan.

Kedua. Penanaman Pohon. Komunitas Sekelik Sedulur menilai bahwa menanam pohon harus sudah menjadi bagian gaya hidup (life style) kita mengingat kondisi alam yang sudah mengalami kerusakan akibat pemansan global atau yang biasa disebut dengan istilah global warming. Penanaman pohon juga bisa diintegrasikan dengan peternakan dan tanaman budidaya. Penghasilan dan pendapatan dari pohon dan hutan lebih aman karena tanaman pohon lebih sedikit tercemar oleh kondisi cuaca yang buruk. Suatu sistem hutan yang dirancang dengan baik akan membutuhkan perawatan yang sedikit begitu sistem ini berhasil dibentuk atau dibangun. Hutan dan pohon-pohon akan memperbaiki kesehatan lingkungan, bukan hanya pada lahan tempat tanaman itu ditanam, tetapi juga pada lingkungan sekitar lahan itu. Bahkan, lingkungan yang baik dan sehat pada daerah pegunungan akan dapat mempengaruhi secara tidak langsung daerah pesisir pantai hingga lingkungan laut.Menyadari pentingnya dan bermanfaatnya pohon bagi lingkungan, komunitas Sekelik Sedulur merasa perlu untuk ikut andil dalam mengkapanyekan signifikansi pohon bagi keberlangsungan alam.

Salah satu kegiatan penanaman pohon yang dilaksanakan oleh komunitas Sekelik Sedulur adalah Gerakan Menanam guna Penghijauan. Kegiatan ini dilaksanakan di daerah aliran sungai Way Seputih, Gunung Sugih, Lampung Tengah pada tanggal 18 April 2016.52 Kegiatan ini diinisiasi oleh komunitas Sekelik Sedulur bekerja sama dengan organisisai Ikatan Pelajar Nahdlatul Ulama (IPNU) cabang Lampung Tengah serta dengan para siswa pengurus OSIS dari beberapa sekolah. Bahkan dalam kegiatan ini komunitas Sekelik Sedulur mengajak beberapa ormas dan tokoh masyarakat untuk berpartisipasi. Melalui kegiatan ini, komunitas Sekelik Sedulur ingin menumbuhkan rasa peduli terhadap lingkungan yang sekarang semakin terkikis. Tokoh-tokoh yang dilibatkan diharapkan dapat menjadi role modelbagi warga lain secara umum. Sehingga satu demi satu warga desa akan menjadi peduli terhadap lingkungan mereka.Apabila tiap individu sudah memiliki perasaan sadar terhadap lingkungan (environmental awareness) maka kegiatan penanaman pohon secara massif pun tidak akan menjadi sesuatu yang sulit untuk dilakukan.

52 Observasi sekelik sedulur dalam penanaman pohon di Wai Seputih Gunung Sugih 18 April 2016

| RI'AYAH, Vol. 02, No. 01 Januari-Juni 2017 
Ketiga, Silaturahm Tokoh. Silaturahmi tokoh juga dilakukan oleh pegiat Komunitas Sekelik Sedulur yang tujuannya adalah meminta restu dan dukungan terhadap gerakan dan kegiatan yang diadakan oleh komunitas. Silaturahim dilakukan terhadap tokoh agama, tokoh adat, tokoh budaya/ budayawan.

Keempat, Refleksi kemerdekaan. Untuk menyatukan seluruh masyarakat Lampung, khususnya Lampung Tengah (Lamteng) untuk tidak membeda-bedakan antara suku, agama, ras dan bahasa. Maka komunitas Sekelik Sedulur berinisiatif untuk menggelar acara dialog kebudayaan refleksi kemerdekaan merajut kebersamaan di tengah keberagaman.

Kelima, Silaturahim dan rembuk warga. Apabila dianalisis dengan seksama, ketika terjadi sebuah konflik antar suku di bumi Ruwa Jurai ini, para pelakunya berasal dari kalangan masyarakat biasa yang tidak memungkinkan sebenarnya sebagian banyak dari mereka kurang tahu menahu apa permasalahannya. Ketidakpahaman ini kemudian sangat mungkin dimanfaatkan oleh oknum-oknum tertentu untuk melancarkan aksi penyerangan atau pengrusakan terhadap suku lain. Apabila hal ini dibiarkan, yang menjadi korban sebenanrnya adalah para warga, para wong cilik itu sendiri. Hal ini tentunya sangat memperihatinkan karena mereka seringkali hanya diperalat saja oleh segelintir orang yang memobilisasi massa sehingga mereka merasa terajak dan merasa harus ikut andil tanpa melihat apa permasalahan sebenarnya.

Merespon realitas ini, komunitas Sekelik Sedulur intens melakukan dialog dan rembug bersama warga di beberapa desa.Sekelik Sedulur menyadai sepenuhnya bahwa ada pemahaman masyarakat yang mulai bergeser. Sehingga pada gilirannya, pemahaman bersama tentang persaudaraan, kebangsaan, dan nilai-nilai persatuan diperlukan.

Keenam, Pentas seni dan dialog budaya. Pentas seni dan dialog kebudayaan sebagai usaha yang dibangun komunitas sekelik sedulur dalam meleburkan kedua budaya lampung dan jawa agar terjadinya akulturasi budaya, sehingga keharmonian antara kegua suku tersebut dapat terjalin dengan baik. Adapun di setiap kegiatan dialog kebudayaan komunitas Sekelik Sedulur selalu bekerja sama dengan berbagai organisasi atau komunitas kemasyarakatan yang lain seperti halnya komunitas Jamuskalimosodo.

Ketujuh, Halal bi halal. Kegiatan ini dimaksudkan oleh komunitas Sekelik Sedulur untuk menjadi media untuk bersilaturahmi dengan warga dan sebagai efektifitas waktu dalam melakukan acara saling memaafkan dan bersalaman. Suasana yang bahagia bulan Syawal semakin membuat kegiatan ini semakin menyenangkan 


\section{Kesimpulan}

Sekelik Sedulur merupakan suatu komunitas yang lahir dari sebuah gagasan sebagai bentuk kepedulian terhadap lingkungan, dengan harapan agar tercipta suasana yang damai, aman, sejahtera di Lampung Tengah khususnya, dan di propinsi Lampung pada umumnya. Komunitas ini menghimpun diri dari setiap suku, etnis, ras, dan agama, tidak hanya terbatas untuk orang Lampung dan Jawa saja penggiatnya, tapi juga membuka diri untuk masyarakat yang ingin bergabung. Untuk mencapai harapan tersebut tentu dukungan dari semua pihak dan golongan diperlukan tanpa memandang perbedaan. Dengan Visi melestarikan budaya lama yang baik dan mengambil budaya baru yang lebih baik, dan Misi menjalin persaudaraan dan menjaga kerukunan ditengah keberagaman. Semoga Sekelik Sedulur senantiasa terikat erat sehingga suasana kondusif khususnya di Kabupaten Lampung Tengah dan umumnya di Provinsi Lampung terus terpelihara. Berasas Pancasila dan UUD 45 dengan semboyan gotong royong, dan berpaham nasionalis, Sekelik Sedulur diharapkan dapat mampu menjadi wadah yang kokoh untuk menjalin silaturahmi antara individu satu dengan yang lainnya dengan beragam latar belakang, dan menjadi simbol perdamaian di Provinsi Lampung. Dalam gerakannya komunitas ini aktif melakukan kegiatan sosial dan membangun jejaring ke tokoh-tokoh adat. Upaya ini yang disebut membangun modal sosial. Kegiatan sosialisasi dilakukan Kampanye Persaudaraan, Kampanye di Lembaga Pendidikan, Pemasangan Stiker, Pemasangan Baliho dan Spanduk. Kampanye malalui Media Sosial. Kegaitan budaya diantaranya Merawat Nilai-nilai Lampung dan Jawa, Nilai-nilai Lampung, Nilai-nilai Jawa, Gerakan Pemuda Sekelik Sedulur, Dialog Kebudayaan, Pentas Seni. Kegiatan Kemasyarakatan diantaranyta Penanaman Pohon, Silaturahmi Tokoh, Refleksi Kemerdekaan, Silaturahmi dan rembug warga, Buka Bersama Sekelik Sedulur, Halal bi Halal Sekelik Sedulur.

Komunitas Sekelik Sedulur dapat menjadi percontohan bagi komunitas lain dalam upaya membangun harmoni antar etnis. Komunitas ini membantu pemerintah dalam meredam konflik. Untuk itu pemerintah daerah harus aktif menghidupkan dialog budaya sebagaimana dilakukan oleh komunitas Sekelik Sedulur di Lampung Tengah. Upaya-upaya ini harus diperkuat oleh elemen lain dalam menguatkan simpul-simpul jejaring masyarakat.

\section{Referensi}

Achmad Fedyani Syaifudin, "Membumikan Multikulturalisme di Indonesia" Jurnal Antropologi Sosial Budaya ETNOVISI, (Jakarta; UI, 2006) Vol II/No I

Alef Theria Wasim dkk. (ed.), Harmoni Kehidupan Beragama: problem, praktek dan pendidikan, Yogyakarta: Oasis Publisher, 2005

Anthony Giddens, Teori Strukturasi untuk Analisis Sosial. (Pasuruan: Pedati, 2003), h. 313

Arizal Mutahir, Intelektual Kolektif Pierre Bourdieu, Yogyakarta: Kreasi Wacana, 2011

| RI'AYAH, Vol. 02, No. 01 Januari-Juni 2017 
Bagus Takwin, Proyek Intelektual Pierre Bourdieu: Melacak Asal-Usul Masyarakat, Melampaui Oposisi Biner dalam Masyarakat, dalam: Harker dkk (ed), (Habitus $x$ Modal) + Ranah = Praktik, Yogyakarta: Jalasutra, 2005

Bethra Ariestha, Akar Konflik Kerusuhan Antar Etnik Di Lampung Selatan (Studi Pada Kerusuhan Antar Etnik Lampung dan Etnik Bali di Lampung Selatan). Skripsi. Jurusan Psikologi Fakultas Ilmu Pendidikan Universitas Negeri Semarang, 2013

Davison, G. dan C Mc Conville. A Heritage Handbook. St. Leonard, NSW: Allen, \& Unwin, 1992

Dean G Pruitt \& Jeffrey . Rubin, Teori Konflik Sosial, Yogyakarta: Pustaka Pelajar, 2004

Frans Magnis Suseno, Melawan Kekerasan Tanpa Kekerasan, Yogyakarta: PP Kesehatan Remaja Muhammadiyah, 2005

Frithjop Schuon, The Transcendent Unity of Religions, New York, London: Harper and Row Publisher, 1975

Galla, A. Guidebook for the Participation of Young People in Heritage Conservation. Brisbane: Hall and jones Advertising, 2001

Geneva Gay, "A Synthesis of Scholarship in Multicultural Education" dalam Urban Education Monograph Series, Washington, NCREL's Urban Education Program, 1994

George Ritzer \& Douglas J. Goodman, Teori Sosiologi Modern, Jakarta: Pernada Media, 2003

Haidlor Ali Ahmad, "Umat Beragama di Kabupaten Kediri: Antara Harmoni dan Konflik", dalam Jurnal Harmoni, Puslitbang Kehidupan Keagamaan Badan Litbang \& Diklat Kementerian Agama RI, Volume X, Nomor 2, April - Juni 2011

Hans Kung, "Sebuah Model Dialog Kristen dan Islam" dalam Jurnal Pemikiran Islam Paramadina, Vol. 1, Nomor 1, Juli-Desember 1998

Haryatmoko, Etika Politik Kekuasaan, Jakarta: Kompas, 2003

Haryatmoko, Sekolah, Alat Reproduksi Kesenjangan Sosial, dalam, Basis, No. 07-08, Tahun ke-57,2008

Heribertus Sutopo, Pengantar Penelitian Kualitatif: Dasar-Dasar Teoritis dan Praktis, Surakarta: Puslit UMS, 1988

Heywood, Andrew. Political Ideologies (3th Edition). (Palgrave: McMillan, 2007). h. 53

J.W.M. Bakker SJ, Filsafat Kebudayaan Sebuah Pengantar, Yogyakarta: Kanisius, 1984

Jamil Salmi, Violence and Demokratic Society, (Yogyakarta: Pilar Media, 2005), h. 32-40

Koentjaraningrat, Ilmu Antropologi. Jakarta: Bhratara, 1988

Koentjaraningrat, Pengantar Ilmu Antropologi, Jakarta: Universitas Indonesia Press, 1990

Koentjaraningrat, Pengantar Ilmu Antropologi. Jakarta: Aksara Baru, 1980

Kymlicka, W, Multicultural Citicenship: Liberal theory of Minority Rights, Oxford: Clarendon Press, 1995

Lexy J. Moleong, Metode Penelitian Kualitatif, Bandung: Remaja Karya, 1989

M. Alie Humaedi, Kegagalan Akulturasi Budaya Dan Isu Agama Dalam Konflik Lampung, Jurnal “Analisa” Volume 21 Nomor 02 Desember 2014 
M. Alie Humaedi. Konflik Komunal Lampung-Bali: Anatomi dan Pemicu Konflik. Laporan Penelitian. Jakarta: LIPI, 2013

M. Sayuthi Ali, Metodologi Penelitian Agama; Pendekatan Teori dan Praktek, Jakarta: PT Raja Grafindo Persada, 2002

Mudhofir Abdullah, Jihad Tanpa Kekerasan, Jakarta: Inti Medina, 2009

Nurcholish Madjid, Islam, Doktrin dan Peradaban: Sebuah Telaah Kritis tentang Masalah Keimanan, Kemanusiaan, dan Kemodernan, Jakarta: Pramadina, 1992

Parekh, B, Rethinking Multiculturalism: Cultural diversity and Political Theory, MacMillan: Press Ltd, 2000

Pierre Bourdieu, Arena Produksi Kultural, Yogyakarta: Kreasi Wacana, 2010

Pierre Bourdieu, The Logic of Practice, Stanford: Stanford University Press, 1992

Putut Ary Sadewo, Dinamika Konflik Agraria dalam kehidupan sosial Masyarakat Sendangayu dan Surabaya Kecamatan Padangratu, Tesis Pascasarjana Pendidikan IPS Fakultas Keguruan dan Ilmu Pendidikan Universitas Lampung, 2014

Suma Riella Rusdiarti, Bahasa, Pertarungan Simbolik dan Kekuasaan, dalam Basis No. 11-12, Th. 52, November-Desember 2003

http://www.pojoksamber.com/komunitas-sekelik-sedulur-sebuah-ikhtiarmembangun-persaudaraan/ diunduh 21 Februari 2015.

http://www.pojoksamber.com/komunitas-sekelik-sedulur-sebuah-ikhtiarmembangun-persaudaraan/ diunduh 21 Februari 2015.

Wawancara Abdul Mukahfi, Koordinaor Komunitas Sekelik Sedulur (2/8/2015). http://lampost.co/berita/anang-prihantoro-hadiri-dialog-kebudayaan-danpentas-seni diunduh 21 Februari 2015.

https://twitter.com/sekeliksedulur diunduh 21 Februari 2015

http://www.radarlamteng.co/?p=516 diunduh 21 Februari 2015

| RI' AYAH, Vol. 02, No. 01 Januari-Juni 2017 